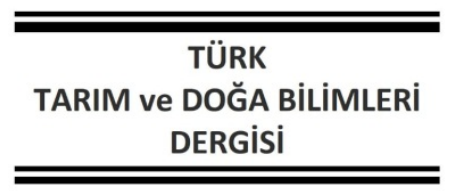

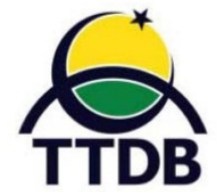

www.dergipark.gov.tr/turkjans Araştırma Makalesi

\title{
Çorum Çevresindeki Yayla Topraklarından İzole Edilen Actinobacteria Üyelerinin Biyosentetik Genlerinin Taranması
}

\author{
Demet $\operatorname{Tatar}^{1 *}$, Aysel Veyisoğlu ${ }^{2}$ \\ ${ }^{1}$ Hitit Üniversitesi, Osmancık Ömer Derindere Meslek Yüksekokulu, Tıbbi Hizmetler ve Teknikler Bölümü, 19500 \\ Çorum, Türkiye \\ ${ }^{2}$ Sinop Üniversitesi, Sağlık Hizmetleri Meslek Yüksekokulu, Tıbbi Hizmetler ve Teknikler Bölümü, 57000 Sinop, \\ Türkiye \\ *Sorumlu Yazar: demettatar@hitit.edu.tr
}

Geliş Tarihi: 08.04.2020 Düzeltme Geliş Tarihi: 22.12.2020 Kabul Tarihi: 06.04.2021

\section{Öz}

Bu çalışmada, Çorum (Kargı ve Osmancık) çevresindeki yaylalardan izole edilen aktinomiset izolatlarının poliketit sentaz ve ribozomal olmayan peptit sentetaz biyosentetik sistemlerinin varlı̆ı̆ moleküler tekniklerle araştırılmıştır. Toplamda 15 tane Actinobacteria üyesinin sekonder metabolit biyosentetik genlerinin (PKS III/NRPS) varlığı PCR temelli incelenmiştir. Yapılan çalışmanın sonuçlarına göre, 15 tane aktinomiset izolatının 7 tanesi PKS-I, 11 tanesi PKS-II ve 14 tanesinin NRPS gen bölgesine sahip olduğu bulunmuştur. Sonuçlar değerlendirildiğinde izolatların nonribozomal peptid sentetaz (NRPS) gen kümelerini tip I-II poliketit sentazlar (PKS-I-II) gen kümelerinden daha fazla içerdiği görülmüştür. Ayrıca 5 izolatın üç gen kümesini bir arada bulundurduğu tespit edilmiştir. Sonuç olarak yaylalardan izole edilen aktinomisetlerin yüksek sekonder metabolit üretme kapasitesine sahip olduğu görülmüştür.

Anahtar kelimeler: Actinobacteria, Yayla Toprağı, PKS-I, PKS-II, NRPS, Biyosentetik Genler

\section{Screening of Biosynthetic Genes of Actinobacteria Members Isolated From Plateau Soils Around Çorum}

\begin{abstract}
In this study, in the presence polyketide synthases and non-ribosomal peptide synthetase biosynthetic system of actinomycete strains isolated from plateau soils located near Çorum (Kargı and Osmancık) was investigated by molecular techniques. Totally of 15 Actinobacteria members presence of secondary metabolite biosynthetic genes (PKS I-II / NRPS) was investigated based on PCR. According to the results of the work done, of the 15 actinomycet isolates, 7 were found to have PKS-I, 11 were PKS-II and 14 had NRPS gene regions. When the results were evaluated, it was observed that the isolates contained more nonribozomal peptide synthetase (NRPS) gene clusters than type I-II polyketide synthase (PKS-I-II) gene clusters. In addition, it was determined that 5 isolates contain three gene clusters together. As a result, it was found that actinomycetes isolated from plateau soils have the capacity to produce high secondary metabolites.
\end{abstract}

Key words: Actinobacteria, Plateau Soil, PKS-I, PKS-II, NRPS, Biosynthetic Genes

\section{Giriş}

Aktinomisetler aerobik, gram-pozitif bakterilerdir. Temel gruplarından birini toprak popülasyonları oluşturmakta olup aktinomisetler çok geniş bir dağılım gösterirler (Kuster, 1968). Actinobacteria üyeleri, hipersalin ortamlar gibi ekstrem habitatlar da dahil olmak üzere akuatik ve karasal habitatlarda geniş dağılım göstermektedir (Ventosa ve ark., 2008). Ayrıca Actinobacteria üyesi olan bazı mikroorganizmalar yağmur ormanları, göl sedimentleri, nehirler ve derin okyanus çukurları dahil olmak üzere farklı ortamlardan elde edilmiştir 
(Wang ve ark., 1999; Terkina ve ark., 2002; Takizawa ve ark., 1993; Colquhoun ve ark., 1998).

Qinghai yaylasının doğusunda yer alan topraktan selülozu parçalayan aktinomisetler üzerine bir çalışma yapılmıştır (Cai ve ark., 2009). Diğer bir çalışmada, İç Moğolistan yaylasındaki kapalı ve otlatmaya açık sulak alanlara ait topraklarda fungus ve aktinomiset çeşitliliğine bakılmıştır (Zhao ve ark., 2011). Orta Afrika Cumhuriyetinde yer alan Bangui yaylası üzerindeki Pama ormanı toprağından yeni bir aktinomiset olan Kibdelosporangium banguiense izole edilerek tanımlanmıştır (Pascual ve ark., 2016). Türkiye'de yapılan başka bir çalışmada Doğu Karadeniz Bölgesi yayla topraklarından farklı aktinomisetlerin izolasyonu gerçekleştirilmiştir (Isik ve ark., 2014).

Antibiyotikler, endüstriyel enzimler ve diğer biyoaktif bileşikler gibi biyoteknolojik ürünler aktinomisetler tarafından sentezlenmektedir (Goodfellow ve ark., 1998; Lam, 2006; Ndonde ve Semu, 2000; Sacramento ve ark., 2004).

En iyi bilinen ve önemli olan antibiyotikler aktinomisetler tarafından üretilmektedir. Bunlar; novobiosin, amfoterisin, vankomisin, neomisin, gentamisin, kloramfenikol, tetrasiklin, eritromisin, nistatin gibi antibiyotiklerdir (Oskay ve ark., 2004).

Aktinomisetlerde,

Streptomycetaceae, Micromonosporaceae ve Pseudonocardiaceae familyalarına ait türler tarafından çok sayıda peptit ve poliketit sentezlenmektedir.

Aktinomisetlerde sekonder metabolit gen kümeleri çoğunlukla kromozom üzerinde yer alır, bazen de plazmitler üzerinde bulunmaktadır. Bu gen kümeleri kromozomun merkezi dışında yer alan bölgelerde bulunmaktadır. Ancak, DNA replikasyonu, transkripsiyon, translasyon ve primer metabolizma gibi gerekli fonksiyonları kodlayan genler genellikle kromozomun merkezindedir (Osbourn, 2010).

Ribozomal olmayan peptit sentetazlar, peptit sentetaz gen kümeleri tarafından kodlanmaktadır. Protein sentezinde olduğu gibi bu enzimler de ribozomlarda sentezlenir. Sekonder metabolitlerin sentezi ise peptit sentetazların kalıp olarak kullanılmasıyla sitoplazmada gerçekleşir. Ribozomal olmayan peptit sentetazlar modül olarak adlandırılan alt birimlerden oluşurlar. Ribozomal olmayan peptit sentetazlar temel olarak Adenilasyon (A), Peptidil taşıyıc protein (PCP) ve Kondensasyon (C) bölgeleri ve ilaveten bir tiyoesteraz (Te) bölgesini de içermektedir. Ayrıca oluşacak ürüne göre, epimerizasyon ve metilasyon gibi bölgeler de modüllerde yer alabilmektedir (Zocher ve Keller, 1997; von Dohren ve ark., 1999; Weber ve Marahiel, 2001).

Poliketit sentazlar da yapısal olarak ribozomal olmayan peptit sentetazlara benzerlik göstermektedir. Poliketitler farmakolojik olarak önemli yeni antibiyotiklerin kaynağını oluşturur (Hertweck, 2009). Poliketit Sentazların Modülünde Yer Alan Temel Bölgeler Açil Transferaz (AT), Açil Taşıyıcı Protein (ACP) ve Ketosentaz (KS) bölgeleridir (Kroken ve ark., 2003).

Gonzalez ve arkadaşları (2005), likenlerden izole ettikleri 337 aktinomiset izolatının PKS-I, PKS-II ve NRPS genlerinin varlığını dejenere PCR primerleriyle araştırmışlardır. İzolatlarının; \% 62.6'sında PKS-I, \% 64.7'sinde PKS-II ve \% 58.5'inde NRPS biyosentetik genlerinin varlığını tespit etmişlerdir.

Karadeniz deniz sedimentlerinden elde edilen 24 denizel aktinomisetin sekonder metabolit biyosentez genleri PKS/NRPS varlığı bakımından PCR tabanlı incelenmiştir (Özcan, 2017).

$\mathrm{Bu}$ çalışmanın amacı Çorum (Kargı ve Osmancık) çevresindeki yaylalardan elde edilen aktinomisetlerin aktif sekonder metabolit sentezleme potansiyellerinin araştırılması ve PKS/NRPS gen bölgelerinin PCR temelli metotlarla taranmasıdır.

\section{Materyal ve Metot}

\section{Aktinomisetlerin Belirlenmesi ve Genomik DNA izolasyonu}

Bu araştırmada Kargı (Eğinönü), Abdullah ve Osmancık Başpınar-Karaca yaylalardan izole edilmiş ve moleküler tekniklerle aktinomiset üyesi olduğu belirlenmiş 15 izolat kullanılmıştır. İzolatlar öncelikle ISP 2 broth ortamına ekilmiş ve $28^{\circ} \mathrm{C}^{\prime}$ de 14 gün boyunca $150 \mathrm{rpm}$ çalkalamalı inkübatörde gelişmeleri sağlanmıştır. Bunu takiben ependorf tüplerine biyokütlesi biriktirilen hücreler, iki kere saf su ile yıkanmıştır. İzolatların genomik DNA izolasyonlarını gerçekleştirmek amacıyla PureLink ${ }^{\circledR}$ Genomik DNA İzolasyon Kiti (Invitrogen, USA) kullanılmıştır. DNA izolasyonu kullanılan kitin üretici firma protokolüne uygun olarak gerçekleştirilmiştir. DNA izolasyonlarının kontrolü \% 1'lik agaroz jel kullanılarak gerçekleştirilmiştir.

\section{PCR Amplifikasyonları ve Reaksiyon Şartları}

Aktinomiset izolatlarının ribozomal olmayan peptit sentetaz (NRPS), poliketit sentaz I ve II gen bölgeleri spesifik primerler (Çizelge 1) ile araştırıldı. NRPS için dejenere primerler adenilasyon domaininin korunmuş amino asit dizilerine göre, PKS-I ketosentaz ve metil-malonil CoA transferaz domainlerinin korunmuş amino asit dizilerine, PKSII ise $\beta$-ketoaçil sentaz ( $\mathrm{KS} \alpha$ ) domaininin korunmuş amino asit dizileri esas alınarak hazırlanmıştır. 
Çizelge 1. NRPS, PKS-I ve II gen bölgeleri amplifikasyonu için kullanılan primerler

\begin{tabular}{|c|c|c|c|c|}
\hline $\begin{array}{l}\text { Gen } \\
\text { Bölgeleri }\end{array}$ & Primerler & Baz Büyüklüğü & $\begin{array}{l}\text { Ürün } \\
\text { Büyüklüğü }\end{array}$ & Referans \\
\hline & A3F(5'GCSTACSYSATSTACACSTCSGG3') & 23 & & Ayuso- \\
\hline NRPS & A7R (5'SASGTCVCCSGTSCGGTAS3') & 19 & $700 \mathrm{bp}$ & $\begin{array}{l}\text { Sacido ve } \\
\text { Genilloud, } \\
2005\end{array}$ \\
\hline \multirow[b]{2}{*}{ PKS-I } & K1F (5'TSAAGTCSAACATCGGBCA3') & 19 & \multirow[b]{2}{*}{$\begin{array}{l}1200-1400 \\
\text { bp }\end{array}$} & А \\
\hline & M6R (5'CGCAGGTTSCSGTACCAGTA3') & 20 & & $\begin{array}{l}\text { Sacido ve } \\
\text { Genilloud, } \\
2005\end{array}$ \\
\hline
\end{tabular}

KS $\alpha \mathrm{F}$ (5'TSGCSTGCTTGGAYGCSATC3') $\quad 20$

PKS-II

Primerlerdeki B: Guanin, sitozin veya timin, S: Guanin veya sitozin, Y: Timin veya sitozin, V: Guanin, adenin veya timin, N: Adenin, timin, sitozin veya guanini ifade etmektedir.

Öncelikle PCR optimizasyonu yapılmış ve en uygun koşullar belirlenmiştir. PCR reaksiyonları 50 $\mu$ toplam hacimde, 250 ng'dan düşük genomik DNA $(2 \mu \mathrm{l}), 0.4 \mathrm{mM}$ her forward ve reverse primer $(1 \mu \mathrm{l})$, DMSO (Merck; $5 \mu \mathrm{l}$ ), GoTaq Hot Start Master Mix (Promega; $25 \mu \mathrm{l}$ ) ve kalan $16 \mu \mathrm{l}$ hacim distile su ile tamamlanmıştır.

Reaksiyon şartları, $95{ }^{\circ} \mathrm{C}$ 'de 5 dakika (ön denatürasyon), $95{ }^{\circ} \mathrm{C}$ 'de 30 saniye (denatürasyon), $54{ }^{\circ} \mathrm{C}^{\prime}$ de 1 dakika bağlanma (K1F/M6R ve KS $\alpha \mathrm{F}$ / $\mathrm{KS} \alpha \mathrm{R}$ primerleri için), $58{ }^{\circ} \mathrm{C}^{\prime}$ de 1 dakika bağlanma (A3F-A7R primerleri için), $72{ }^{\circ} \mathrm{C}$ 'de 4 dakika uzama (30 döngü) ve $72{ }^{\circ} C^{\prime}$ de 10 dakika uzama (30 döngü) olacak şekilde gerçekleştirildi.

\section{Bulgular}

Yapılan bu çalışmada 15 aktinomiset izolatında modüler PKS I, PKS II (Shen, 2003) ve nonribozomal peptid sentetaz (NRPS) gen kümelerinin varlığının olup olmadığı tespit edilmiştir (Tablo 2). NRPS gen bölgesi PCR amplifikasyonu sonucu 700 bp ürün elde edilirken, PKS-I gen bölgesi PCR amplifikasyonu sonucu 1200-1400 bp ürün ve PKS-II gen bölgesi PCR amplifikasyonu sonucu 613 bp ürün elde edilmiştir. İzolatların 14'inde NRPS gen bölgesi, 7'sinde PKS-I gen bölgesi ve sadece 11 izolatta PKS-II gen bölgesi bulunmaktadır. İzolatların 5 tanesinde ise üç gen bölgesi bir arada bulunmaktadır (Şekil 1 ve Çizelge 2 ).

\section{Tartışma ve Sonuç}

Yapılan çalışmada Çorum çevresindeki yaylalardan elde edilen 15 aktinomiset izolatının Poliketit Sentaz ve Ribozomal Olmayan Peptit Sentetaz biyosentetik sistemlerini içerip içermedikleri araştırılmıştır (Çizelge 2). Bakteriler tarafından sentezlenen antimikrobiyal maddelerin tarama çalışmalarında klasik yaklaşımlar yerine günümüzde alternatif moleküler yöntemler kullanılmaktadır. Klasik yöntemde, fermentörde kültüre edilen organizma antimikrobiyal aktivite bakımından test edilmektedir. Alternatif metotta ise biyoaktif bileşiklerin sentezini kontrol eden biyosentetik genlerin taraması yapılmaktadır. Modüler PKS I, PKS II (Shen, 2003) ve nonribozomal peptid sentetaz (NRPS) gen kümeleri, aktinomisetlerde çok sayıda yapısal olarak birbirinden farklı sekonder metabolitlerin sentezinden sorumlu gen kümeleridir. PKS I, PKS II ve NRPS gen bölgeleri için özel dizayn edilmiş primerlerle biyosentetik enzimlerin hızlı ve doğru bir şekilde belirlenmesi mümkündür. Bu çalışmada da literatürde yaygın kullanılan primerler tercih edilmiştir (Çizelge 1). İzolatların 14 tanesi NRPS genini taşımaktadır (Çizelge 2). 7 tanesi PKS-ı gen bölgesi ve 11 taneside PKS-II gen bölgesini içermektedir. İzolatların 5 tanesinde ise üç gen bölgesi bir arada bulunmaktadır (Şekil 1 ve Çizelge 2). 
Çizelge 2. İzolatların NRPS, PKS-I ve PKS-II gen bölgelerinin PCR amlifikasyonu

\begin{tabular}{|c|c|c|c|c|}
\hline No & İzolat kodu & NRPS & PKS-I & PKS-II \\
\hline 1 & B1AY & + & - & + \\
\hline 2 & B2BY & + & - & + \\
\hline 3 & B2KY & + & + & + \\
\hline 4 & H1BY & + & + & - \\
\hline 5 & H1KY & + & - & + \\
\hline 6 & H2AY & + & + & + \\
\hline 7 & GA1AY & - & - & + \\
\hline 8 & GA2AY & + & + & - \\
\hline 9 & GA2KY & + & - & + \\
\hline 10 & NZ1AY & + & + & + \\
\hline 11 & NZ1KY & + & + & + \\
\hline 12 & NZ2BY & + & + & + \\
\hline 13 & SC1AY & + & - & - \\
\hline 14 & SC1BY & + & - & - \\
\hline 15 & SC1KY & + & - & + \\
\hline
\end{tabular}

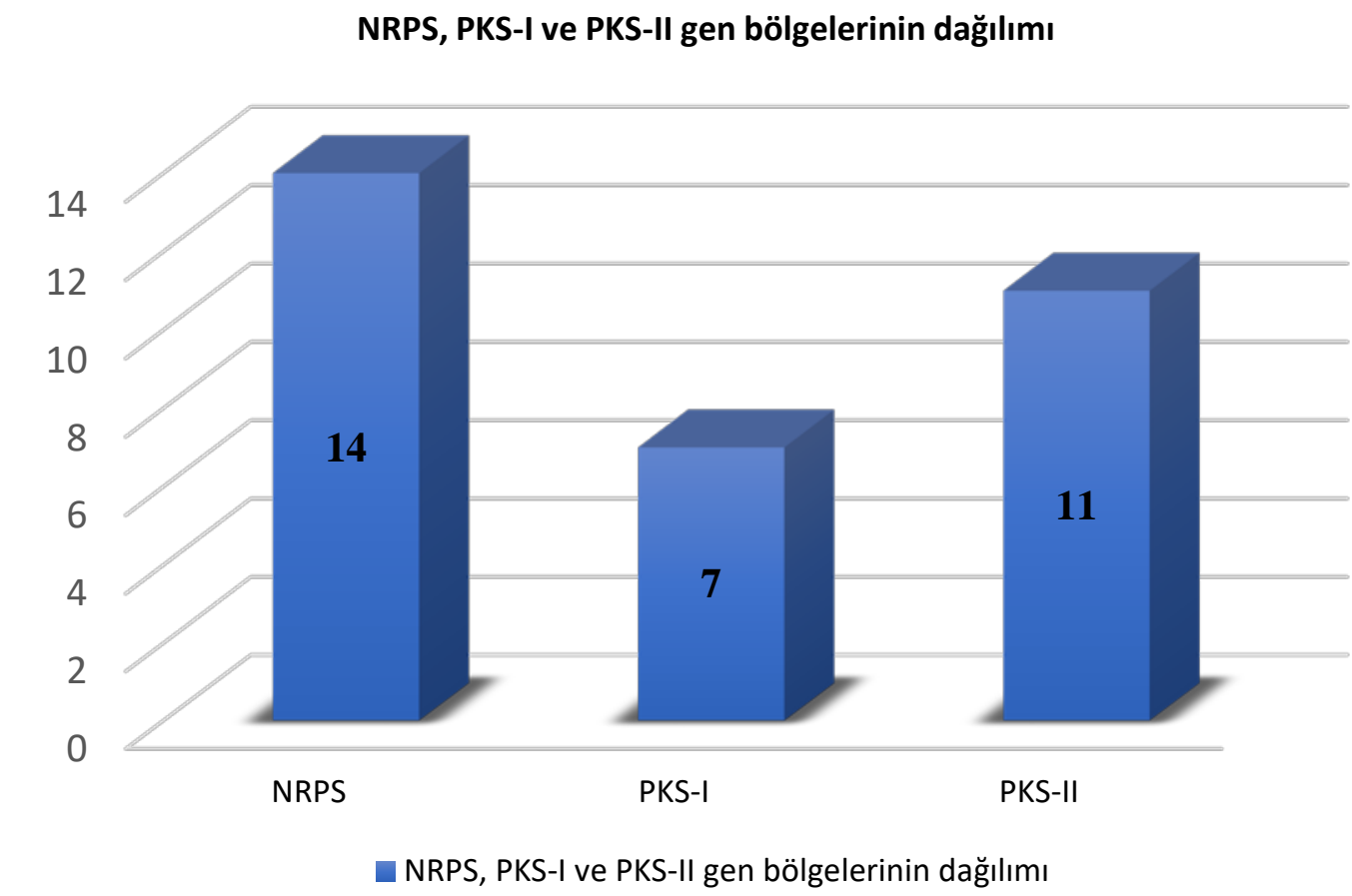

Şekil 1. İzolatların NRPS, PKS-I ve PKS-II gen bölgelerinin dağılımı 
Tıpta, tarımda ve biyokimyasal araştırmalarda geniş alandaki uygulamalara sahip, biyolojik olarak aktif poliketid ve peptid bileşikleri, tip I poliketid sentazlar (PKS-I) ve nonribozomal peptid sentetazlar (NRPS) tarafından sentezlenir.

$\mathrm{Bu}$ yapısal olarak çeşitli metabolitler, antifungaller (örneğin nistatin-poliketit), antitümör ajanlar (örneğin ansamitosin-poliketit, bleomisinhibrit poliketit peptit), antihelmintikler (örneğin avermektin-poliketit) ve immunosupressive ajanlar (örneğin rapamisin-poliketit ve FK506-poliketit) ve diğer antibiyotikler (örneğin penisilinler-peptit, vankomisin-peptit ve eritromisin-poliketit) arasında yer alır (Ayuso-Sacido ve Genilloud, 2005).

Çorum çevresindeki yaylalardan elde edilen 15 aktinomisetin 14'ünde NRPS, 7'sinde PKS-I ve 11 tanesinde de PKS-II gen bölgesinin olması bu bölgeden elde edilen aktinomisetlerin sekonder metabolit üretme potansiyeli bakımından oldukça önemli olduğunu göstermektedir. NRPS ve PKS I-II gen bölgelerinin genomda bulunması aktif sekonder metabolit sentezini kesin gerçekleştireceği anlamına gelmemektedir ancak böyle bir sekonder metabolit potansiyelinin var olabileceği ile ilgili fikir vermektedir. Daha sonraki çalışmalarda bu gen bölgelerinin detaylı bir şekilde aydınlatılması ile yeni sekonder metabolitlerin varlığı belirlenebilir.

\section{Teşekkür}

$\mathrm{Bu}$ çalışma Hitit Üniversitesi Bilimsel Araştırma Projeleri Koordinasyon Birimi tarafından ODMY019003.18.001 numaralı proje olarak desteklenmiştir. Çalışmaya olan katkılarından dolayı Ondokuz Mayıs Üniversitesi Moleküler Biyoloji ve Genetik Bölüm Başkanı Prof. Dr. Nevzat ŞAHiN'e şükranlarımı sunuyorum.

Çıkar Çatışması Beyanı: Makale yazarları aralarında herhangi bir çıkar çatışması bulunmamaktadır.

Araştırmacıların Katkı Oranı Beyan Özeti: Yazarlar makaleye eşit oranda katkı sağlamıştır.

\section{Kaynaklar}

Ayuso-Sacido, A., Genilloud, O. 2005. New PCR Primers for the Screening of NRPS and PKSI Systems in Actinomycetes: Detection and Distribution of These Biosynthetic Gene Sequences in Major Taxonomic Groups, Microbial Ecology., 49:10-24.

Cai, Y., Xue, Q., Chen, Z., Zhang R. 2009. Study on Cellulose-decomposed Actinomycetes in Soil in the Eastern of the Qinghai Plateau, Modern Applied Science, 3(2):83.
Colquhoun, J.A., Heald, C.S., Li, L., Tamaoka, J. and others. 1998. Taxonomy and biotransformation activities of some deep sea actinomycetes, Extremophiles, 2:269277.

Gonzalez, I., Ayuso-Sacido, A., Anderson, A., Genilloud, O. 2005. Actinomycetes isolated from lichens: Evaluation of their diversity and detection of biosynthetic gene sequences, FEMS Microbiology Ecology, 54:401-415.

Goodfellow, M., Stainsby, F.M., Davenport, R., Chun, J., Curtis, T.P., 1998. Activated sludge foaming: the true extent of actinomycetes diversity, Water Sci. Technol., 37:511-519.

Hertweck, C. 2009. The Biosynthetic Logic of Polyketide Diversity, Angew. Chem. Int. Ed., 48:4688-4716.

Isik, K., Gencbay, T., Ozdemir-Kocak, F., Cil, E.. 2014. Molecular identification of different actinomycetes isolated from East Black Sea region plateau soil by 165 rDNA gene sequencing, Afr. J. Microbiol. Res., 8(9):878-887.

Kuster, E., 1968. The actinomycetes. In: Soil Biology, eds. Burges (A.) \& Raw (F.), Academic Press, London.

Kroken, S., Glass, N.L., Taylor, J.W., Yoder, O.C., Turgeon, B.G. 2003. Phylogenomic analysis of type I polyketide synthase genes in pathogenic and saprobic ascomycetes, Proceedings of the National Academy of Sciences of the United States of America, 100:15670-15675.

Lam, K.S. 2006. Discovery of novel metabolites from marine actinomycetes, Curr. Opin. Microbiol., 9:245-251.

Metsä-Ketelä, M., Salo, V., Halo, L., Hautala, A., Hakala, J., Mäntsälä, P., Ylihonko, K. 1999. An efficient approach for screening minimal PKS genes from Streptomyces, FEMS Microbiol. Lett., 180:1-6.

Ndonde, M.J.M., Semu, E. 2000. Preliminary characterization of some Streptomyces species from four Tanzanian soils and their antimicrobial potential against selected plant and animal pathogenic bacteria, World J. Microbiol. Biotechnol., 16:595599.

Osbourn, A. 2010. Secondary metabolic gene clusters: Evolutionary toolkits for chemical innovation, Trends Genet., 26:449-457.

Oskay, M., Tamer, A.U., Azeri, C. 2004. Antibacterial activity of some Actinomycetes isolated from farming soils of Turkey, Afr. J. Biotechnol., 3:441-446. 
Özcan, K. 2017. Trabzon (Karadeniz) Deniz Sedimentlerinden Elde Edilen Denizel Aktinomisetlerin Sekonder Metabolit Biyosentez Genlerinin Taranması, Türk Tarım - Gıda Bilim ve Teknoloji Dergisi, 5(5):502-506.

Pascual, J., González, I., Estévez, M., Benito, P., Trujillo, M.E., et al. 2016. Description of Kibdelosporangium banguiense sp. nov., a novel actinomycete isolated from soil of the forest of Pama, on the plateau of Bangui, Central African Republic. Antonie van Leeuwenhoek, 109:685-695.

Sacramento, D.R., Coelho, R.R.R., Wigg, M.D., Linhares, LFTL., Santos, M.G.M., Semedo, LTAS. 2004. Antimicrobial and antiviral activities of an actinomycetes (Streptomycin sp.) isolated from a Brazilian tropical forest soil, World. J. Microbiol. Biotechnol., 20:225-229.

Shen, B. 2003. Polyketide biosynthesis beyond the type I, II and III polyketide synthase paradigms, Curr. Opin. Chem. Biol., 7:285295.

Takizawa, M., Colwel, R.R., Hill, R.T. 1993. Isolation and diversity of actinomycetes in the Chesapeake Bay, Appl. Environ. Microbiol., 59:997-1002.

Terkina, I.A., Drukker, V.V., Parfenova, V.V., Kostornova, T.Y. 2002. The biodiversity of actinomycetes in Lake Baikal, Microbiology, 71:346-349.

Wang, Y., Zhang, Z.S., Ruan, J.S., Wang, Y.M., Ali, S.M. 1999. Investigation of actinomycete diversity in the tropical rainforests of Singapore, J. Ind. Microbiol., 23:178-187.

Weber, T., Marahiel, M,A. 2001. Exploring the domain structure of modular nonribosomal peptite synthetases, Structure, 9:3-9.

Ventosa, A., Mellado, E., Sanchez-Porro, C., Marquez, M.C. 2008. Halophilic and halotolerant microorganism from soils, In: Dion, P, Nautiyal, C.S (eds) Microbiology of extreme soils. Springer-Verlag, Berlin, Heidelberg, pp. 87-115.

Von Dohren, H., Dieckmann, R., Pavela-Vrancic, M. 1999. The nonribosomal code, Chemistry and Biology, 6:273-279.

Zhao, J., Shao, Y., Zhao, Z., Liu, F., Zhou, H., Li, Z. 2011. Diversity of Fungi and Actinomycetes in Soil of Enclosed and Grazing Wetland on Inner Mongolian Plateau, Advanced Materials Research Vols. 356-360, pp.2703-2706.

Zocher, R., Keller, U. 1997. Thiol template peptite synthesis systems in bacteria and fungi, Advances in Microbial Physiology, 38:85131. 